\title{
COLLABORATION CAPABILITY - \\ A FOCAL CONCEPT IN KNOWLEDGE CREATION AND \\ COLLABORATIVE INNOVATION IN NETWORKS
}

\author{
Blomqvist $\mathrm{K}^{1}$. and Levy $\mathrm{J}^{2}$ \\ Telecom Business Research Center and Department of Business Administration \\ Lappeenranta University of Technology
}

\begin{abstract}
In the knowledge-based competition sustainable competitive advantage is not possible without continuous innovation. Innovations, by nature, emerge in network interaction where diverse actors share complementary knowledge. Collaboration capability is seen as a fundamental issue for actors to leverage complementary knowledge.

The concept of collaboration capability concept is first analysed based on a state-of-the-art review on earlier conceptual and empirical research on network collaboration. As a result of our analysis we propose that collaboration capability integrates the key elements in many closely related, but semantically diverse conceptualisations. As a concept it underlines the relational perspective and enables knowledge creation in a risky and uncertain environment. Collaboration capability can be defined as "actor's capability to build and manage network relationships based on mutual trust, communication and commitment". It is proposed that collaboration capability may be an integrating, and cross-level concept explaining much of the knowledge creation and innovation in networks.
\end{abstract}

Keywords: collaboration capability, knowledge creation, innovation, inter-organisational relationships, intra-organisational collaboration, teams, networks.

\footnotetext{
${ }^{1}$ Professor Kirsimarja Blomqvist, Department of Business Administration and Telecom Business Research Center, Lappeenranta University of Technology, P.O. BOX 20, 53851 LAPPEENRANTA, FINLAND kirsimarja.blomqvist@lut.fi; +358(40) 7551693 (corresponding author)

${ }^{2}$ Research assistant Juha Levy, Department of Business Administration and Telecom Business Research Center, Lappeenranta University of Technology, P.O. BOX 20, 53851 LAPPEENRANTA, FINLAND juha.levy@lut.fi
} 


\section{INTRODUCTION}

Global competition has reduced the role of traditional sources of competitive advantage. Technological knowledge is critical, but no more a source for sustainable competitive advantage. A new, fundamental factor for wealth creation is continuous knowledge creation and innovation in networks. Complementary knowledge is needed to breed innovative ideas to products and services. Knowledge creation is social in nature, social exchange is a core process in knowledge creation and also friction is always part of social organizing (Brown and Duguid 1998). Nonaka and Takeuchi (1995) also stress the importance of common values, goals and strong relationships in knowledge creation. Subsequently mutual communication based on trust is seen as critical for knowledge creation and subsequent innovation (Miles et al. 2000). Miles et al. (2000) further point out that the ability to collaborate is a meta-capability for innovation. Also many practitioners pay attention to collaboration as a critical issue in a network economy. According to Nokia CEO Pekka Ala-Pietilä the only thing discerning really successful Nokia managers is their capability to establish relationships both within Nokia and with external parties (Ala-Pietilä, 2003).

In this paper we study and analyse the concept of collaboration capability. Based on earlier research the theoretical approaches and contexts relevant to collaboration capability are discussed. Thereafter the concept is analysed at different level of analysis, e.g. individual, team, intra- and interorganisational collaboration. Thereafter a conceptualisation for collaboration capability is offered, and it is proposed that collaboration capability may be an integrating, and cross-level concept explaining much of the knowledge creation and innovation in networks. The role of collaboration capability in knowledge creation and innovation, as well as the relationship between collaboration capability and performance are discussed. Paper concludes with managerial implications and topics for further research.

\section{ON COLLABORATION CAPABILITY AND RELATED CONCEPTS IN RECENT RESEARCH}

Discussion on collaboration capability and related terms can be traced back to several theoretical approaches. Literature is thus fragmented and providing a comprehensive view is challenging. In the following sub-chapter we review the main theoretical approaches, the contexts for collaboration capability or closely related concepts, and the level of analysis. We also discuss its role and potential as a unifying and cross-level concept integrating key aspects in related concepts. 


\subsection{Theoretical Approaches behind Collaboration Capability}

Theoretical approaches behind collaboration capability are closely related to the developing theory of the firm: the resource-based view (Wernerfelt 1984; Barney, 1991), knowledge-based view of the firm (Nonaka and Takeuchi 1995), the dynamic capability view (Teece et al., 1997; Eisenhardt and Martin, 2000), and the competence-based view (Prahalad and Hamel, 1990). According to knowledge-based view of the firm individually and organizationally held knowledge is seen as a basis for firm-level capabilities and a source of competitive advantage (Grant, 1996). Collaboration capability can be seen as a subset of dynamic capabilities (Teece et al. 1997) or combinative capabilities (Kogut and Zander 1993), and also a meta-capability enabling dynamic capabilities (Blomqvist and Seppänen 2003).

Discussion and related theory on firm-specific capabilities is of wide interest and has great managerial potential. It is however in a pre-paradigmatic phase in a sense, that there is no agreement on conceptualization and operationalization of focal concepts. Different authors use terms differently and give specific meaning to certain terms. Hamel and Prahalad (1990) made the core competence known to a wider public. Teece et al. (1997) approach firm performance through dynamic capability view of the firm. They don't however refer to collaboration itself as a dynamic capability, even if a careful reader can pinpoint alliances, acquisitions, intra-organizational strategy process, and R\&D as operations demanding strong collaboration (see e.g. Eisenhardt and Martin 2001). It is thus proposed that collaboration capability can be seen as a generic meta-capability enabling leverage of both internal and external knowledge bases for changing needs in uncertain and complex environment.

\subsection{Level of Analysis and Conceptualizations for Collaboration Capability}

In recent literature on alliances, cross-functional teams, and intra-firm innovation the term collaboration capability or closely connected concepts have been discussed at different level of analysis. In this sub-chapter collaboration capability or connected concepts will be discussed at various levels: individual level, team level, intra-organizational level, inter-organizational level, and network levels.

At individual level e.g. Buckley et al. (2002) draw attention to managers' partnering skills in crosscultural joint ventures. Also Wieselquist et al. (1999) as well as Morgan and Hunt (1994) identify trust and commitment to lead to pro-relationship behaviors in customer relationships and relationship marketing. In a similar context Storbacka et al. (1994) approach relationship quality as consisting of 
commitment, communication, bonds and satisfaction. Crosby et al. (1990) define relationship quality with the dimensions of trust and satisfaction.

At team level the collaboration of a team is referred to as team integration (Swink 1999) or crossfunctional cooperation (Pinto et al. 1993) or as collaborative cross-functional integration (Ellinger 2000). Järvenpää and Leidner (1999) see trust and communication as team success factors. Vartiainen et al. (2003) have defined team's collective competence as consisting of trust, commitment, communication and joint problem solving.

At intra-organisational level Kahn and Mentzer (1996 and 1998) have identified two separate philosophies for managing interdepartmental interaction: transaction-based interaction and collaboration philosophy. Interdepartmental integration as collaboration implies common goals, shared values, mutual commitments, and collaborative behaviour. This approach parallels e.g. relationship marketing in the field of marketing. In transaction-based philosophy departments are considered to be independent entities competing for company resources. Thus transactional and relational approaches can be discerned also at a firm level.

At intra-organisational level researchers approach collaboration capability from the perspective of interdepartmental integration (Kahn and Menztzer 1996 and 1998; Ellinger et al. 2000) and as crossfunctional integration (Swink 1999). Hausman et al. (2000, 241) discuss inter-functional interfaces or inter-functional harmony referring to department's capability to work cross-departmental borders. Kahn (1996, 9-10) has defined interdepartmental collaboration as "the willingness of departments to work together, which emphasizes working together, having mutual understanding, having a common vision, sharing resources, and achieving collective goals". Collaboration is further characterized as the attitudinal aspect of interdepartmental relationships, representing and affective, volitional, mutual/shared process (Kahn 1996, 9-10). Interdepartmental integration has been also characterised and operationally defined as information sharing and involvement (Gupta, Raj and Wilemen 1986 in Kahn 1998). According to Tyler (2001), collaborative capabilities consist of information processing, communication, knowledge transfer and control, management of intra- and inter-unit co-ordination, trustworthiness/ability to engender trust and negotiation skills.

Studies on intra-organisational collaboration seem to underline the informal side of collaboration and especially the role of informal communication, instead of formal reporting and consulting. Literature addressing cross-functional integration ranges from logistics and marketing or production (Kahn and 
Mentzer 1996 and 1998, Ellinger et al. 2000), to new product development and manufacturability (Ellinger et al. 2000).

At inter-organisational level relationships are seen to generate more value and competitive advantage if they become more relational instead of transactional and market-based (Dyer and Singh 1998). Relational rents are seen to rise from investments in relationship-specific assets, knowledge exchange and learning and complementary capabilities. Subsequently, for firms to be able and willing to develop relationship-specific assets, to invest in knowledge exchange and learning and to be able to lower transaction costs, a need for strong collaboration capability can be assumed.

In the context of alliances and dyadic partnerships Lambe, Spekman and Hunt $(2002,143)$ discuss alliance competence when they refer to "organisational ability to find, develop and manage relationships". Kale et al. (2002, 750) introduce term alliance capability, which means in organizational level "specific systems to capture, codify, communicate and create alliance management lessons and insights associated with their alliance experience". According to Heimeriks and Duysters $(2003,9)$ alliance capabilities are " the mechanisms that help firms engage in a stable and repetitive activity pattern to capture, share, disseminate and apply alliance management knowledge (or know-how and know-why)". They add an 'application' element introduced by Makadok (2001) on Kale's et al. (2002) definition, which means concrete micro-level mechanisms e.g. databases or alliance department which systematically capture and share alliance experience. It seems that authors discussing alliance capability stress the capability to learn from individual experiences and past to become better in alliances. They clearly have an organizational learning perspective and use the concept of alliance capability at the organizational level.

Sivadas and Dwyer $(2000,33)$ discuss cooperative competency and define it as "the ability of the partners to trust, communicate, and coordinate". Niemelä's (2003) multi-dimensional conceptualization on co-operation capability consist of the "components of social 'networking' capabilities, management capabilities and learning capabilities which together with trust and commitment are seen as the key capabilities in the networking process of family firms " (Niemelä 2003, 9).

Ritter et al. (2002) have developed a concept of network competence to understand the role of network management in innovation success. They define it as "the degree of network management task execution and the degree of network management qualification possessed by the people handling a company's relationships" (Ritter et al. 2002, 120). In Ritter et al's (2002, 2003) two- 
dimensional construct of network competence the qualifications dimension incorporate social qualifications such as ease of communication and reliability stress collaborative aspects.

At network level both the actor's position as well as structure of the network is of importance (Gulati et al. 2000). Actors gain information and complementary competencies through networks. In IMP tradition e.g. Ford (2002) has proposed that the relevant unit of analysis is the network, and not a single firm. Only few of the researchers, e.g. Duysters et al. (2003) have depicted the firm, alliance and network levels in research on alliances. They refer to Gulati et al. (2000) and according to this view firms can be seen as architects designing networks. Duysters et al. (2003) try to understand inter-organizational relationships at network level through the social capital theory. It underlines by definition the relationship perspective and approaches trust, norms and relationships as critical components of social capital (Putnam 1993).

\subsection{Towards an Integrating and Cross-Level Concept of Collaboration Capability}

Cross-level analysis is not usual. In the state-of-the-art review very few researchers have approached network interaction and related collaboration in a holistic way. However, e.g. Weiss $(1993,278)$ argues "in complex social phenomena, actors exist on more than one level (simultaneously), act differently as units and influence each other across levels". In similar vein Rousseau et al. (1998) call for multiple levels of analysis to understand organisational and inter-organisational phenomena, such as trust.

Tyler (2001) sees co-operative capabilities as multi-dimensional capability that complements and may even substitute technological capabilities. In Tyler's definition on co-operative capabilities cooperation itself is seen as any "process by which individuals, groups, and organisations come together, interact, and form psychological relationships for mutual gain or benefit" (Tyler 2001, 4; originally from Smith et al. 1995, 10). Tyler (2001) further argues for multi- and cross-level character of co-operative capabilities that reside in individuals, and not just in organisational systems or routines. Also Hillebrand and Biemans $(2003,737)$ argue that a linkage between different levels of collaboration is critical to understand the systemic nature of network collaboration. As an example of necessary linkages, intra-organisational collaboration capability can be seen as a necessary antecedent for successful inter-organisational collaboration.

Duysters et al. (2003) proposes that firms need to pay attention to different levels to manage alliances in an optimal way. In similar way than learning and innovation (see Kanter 1988), and trust (Rousseu 
et al. 1998), also collaboration capability can be best understood within a context of multiple levels of analysis. Subsequently, collaboration capability can be seen as a multi- and cross-level concept (see Tyler 2001, Rousseau 1985 and Rousseau et al. 1998). It is a critical issue at all levels of analysis, and the same concept may be useful to understand and analyse different levels of analysis (Figure 1).

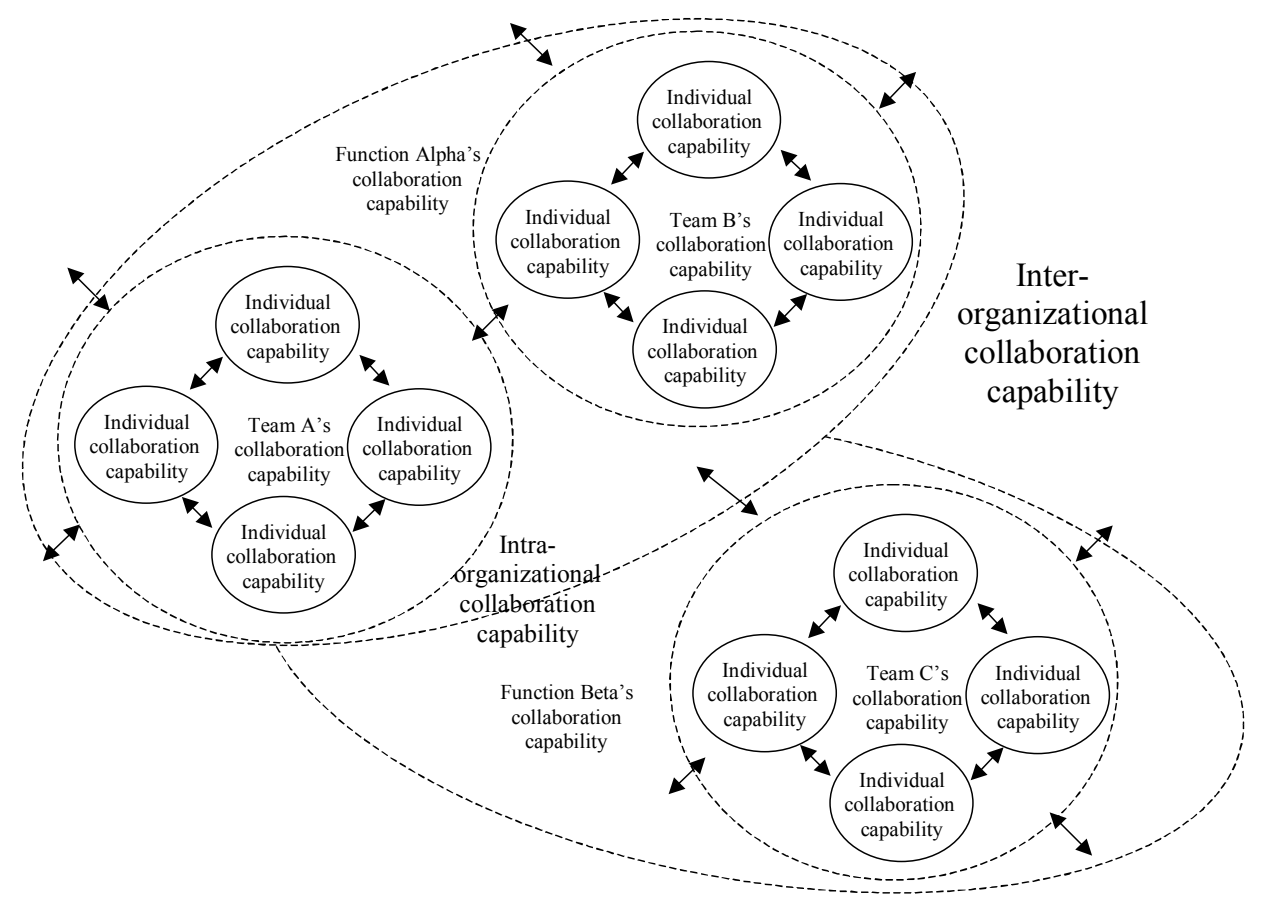

Figure 1. Linkages of Collaboration Capability at Different Levels of Analysis

Different level of analysis can be seen as part of the fractal ranging from collaboration of individuals to network collaboration of firms. On the other hand the different parts of the system impact each other, and the collaboration capability of the system is augmented by the capabilities of its parts. It is proposed that collaboration capability is a useful cross-level concept to both understand, and analyse relational interaction at different levels: individual, team, intra-organisational and interorganisational levels

In this paper we have concentrated on the concept of collaboration capability that is based on relational orientation as the opposite of transactional orientation (Dyer and Singh 1998). Relational orientation is associated with high levels of trust and two-way communication. Miles et al. (2000) and (2004) emphasize the difference between cooperation, collaboration, co-opetition and competition. According to them the term collaboration is specific and should be reserved to collaboration based on voluntary interaction, trust and commitment, instead of cooperation, where actors co-operate based on external motivation e.g. money. Many researchers interested in 
collaboration highlight the "soft" components of trust, communication and commitment. Literature seems to acccumulate well in this sense (see Table 1).

Table 1. Concepts and Dimensions Related to Collaboration Capability

\begin{tabular}{|c|c|c|c|c|c|c|c|}
\hline Unit of analysis & Interpersonal & & & Dyad & & & \\
\hline Term & $\begin{array}{l}\text { Relationship } \\
\text { success } \\
\text { factors }\end{array}$ & $\begin{array}{l}\text { Relationship } \\
\text { quality }\end{array}$ & $\begin{array}{l}\text { Relationship } \\
\text { quality }\end{array}$ & $\begin{array}{l}\text { Characteristic } \\
\text { of } \\
\text { partnership } \\
\text { success }\end{array}$ & $\begin{array}{l}\text { Success } \\
\text { determinants } \\
\text { of long-term } \\
\text { orientation }\end{array}$ & $\begin{array}{l}\text { Cooperative } \\
\text { competence }\end{array}$ & $\begin{array}{l}\text { Relationship } \\
\text { capital }\end{array}$ \\
\hline $\begin{array}{l}\text { Authors } \\
\text { Concept }\end{array}$ & $\begin{array}{l}\text { Morgan \& } \\
\text { Hunt (1994) }\end{array}$ & $\begin{array}{l}\text { Storbacka, } \\
\text { Strandvik \& } \\
\text { Grönroos } \\
1994\end{array}$ & $\begin{array}{l}\text { Crosby, } \\
\text { Evans \& } \\
\text { Cowles } \\
1990\end{array}$ & $\begin{array}{l}\text { Mohr \& } \\
\text { Spekman } \\
1994\end{array}$ & $\begin{array}{l}\text { Ganesan } \\
1994 ; 1996\end{array}$ & $\begin{array}{l}\text { Sivadas and } \\
\text { Dwyer } \\
2000\end{array}$ & $\begin{array}{l}\text { Sarkar, } \\
\text { Echambadi, } \\
\text { Cavusgil \& } \\
\text { Aulakh } \\
2001\end{array}$ \\
\hline Trust* & $\checkmark$ & & $\checkmark$ & $\checkmark$ & $\checkmark$ & $\checkmark$ & $\checkmark$ \\
\hline Commitment* & $\checkmark$ & $\checkmark$ & & $\checkmark$ & & & $\checkmark$ \\
\hline Communication* & & $\checkmark$ & & $\checkmark$ & & $\checkmark$ & $\checkmark$ \\
\hline Coordination & & & & $\checkmark$ & & & \\
\hline $\begin{array}{l}\text { Joint problem } \\
\text { solving }\end{array}$ & & & & $\checkmark$ & & & \\
\hline Dependence & & & & & $\checkmark$ & & \\
\hline Satisfaction & & $\checkmark$ & $\checkmark$ & & & & \\
\hline
\end{tabular}

\begin{tabular}{|c|c|c|c|c|c|c|c|}
\hline Unit of analysis & Team level & & Firm level & & & & \\
\hline Term & & $\begin{array}{l}\text { Collective } \\
\text { competence }\end{array}$ & $\begin{array}{l}\text { Cooperative } \\
\text { capabilities }\end{array}$ & Integration & $\begin{array}{l}\text { Co- } \\
\text { operation } \\
\text { capability }\end{array}$ & $\begin{array}{l}\text { Network } \\
\text { competence }\end{array}$ & $\begin{array}{l}\text { Alliance } \\
\text { success } \\
\text { factors }\end{array}$ \\
\hline $\begin{array}{l}\text { Authors } \\
\text { Concept }\end{array}$ & $\begin{array}{l}\text { Järvenpää } \\
\text { \& Leidner } \\
\text { (1999) }\end{array}$ & $\begin{array}{l}\text { Vartianen et } \\
\text { al. (2003) }\end{array}$ & Tyler (2001) & $\begin{array}{l}\text { Kahn and } \\
\text { Mentzer } \\
\text { (1998) }\end{array}$ & $\begin{array}{l}\text { Niemelä } \\
(2003)\end{array}$ & $\begin{array}{l}\text { Ritter \& } \\
\text { Gemunden } \\
(2003)\end{array}$ & $\begin{array}{l}\text { Duysters, } \\
\text { Heimeriks \& } \\
\text { Jurriens } \\
(2003) \\
\end{array}$ \\
\hline Trust* & $\checkmark$ & $\checkmark$ & $\checkmark$ & & $\checkmark$ & $\checkmark$ & $\checkmark$ \\
\hline Commitment* & & $\checkmark$ & $\checkmark$ & $\checkmark$ & $\checkmark$ & & \\
\hline Communication* & 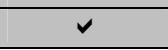 & $\checkmark$ & $\checkmark$ & $\checkmark$ & & $\begin{array}{c}r \\
\end{array}$ & $\checkmark$ \\
\hline Coordination & & & $\checkmark$ & & & & \\
\hline $\begin{array}{l}\text { Joint problem } \\
\text { solving }\end{array}$ & & $\checkmark$ & & & & & \\
\hline \multicolumn{8}{|l|}{ Dependence } \\
\hline Satisfaction & & & & & & & \\
\hline
\end{tabular}

*Our concept

Based on Table 1 it seems that various authors agree on the critical role of trust, commitment and communication for collaboration. Authors conceptualizations vary e.g. from collective competence (team level, Vartiainen et al. (2003) to co-operation capability (co-operation capability, Niemelä 2003) and network competence (Ritter and Gemunden, 2003). Following other authors who have used a similar conceptualization; we consider relational orientation to be comprised of trust, communication and commitment (Sarkar, et al., 2001; Pillai \& Sharma 2003; Heide \& John 1992; 
Morgan \& Hunt 1994; Irwin et al. 1998). We propose that trust, communication and commitment differentiate relationally oriented relationships from transactional relationships based mainly on economic logic and short-term benefits. Also the more traditional factors of inter-organizational relationships, such as coordination, transaction costs or enabling technologies are important, but not enough for collaborative innovation characterized by high risks and uncertainty. Under conditions of high uncertainty the role of collaboration capability is accentuated (Tyler 2001, Amit and Schoemaker 1993, Miller and Shamsie 1996). Relational approach is proposed to be both economically viable and necessary in collaborative innovation demanding high investments in human and intellectual capital.

Based on previous literature on collaboration at different levels of analysis, we base our definition on critical factors in collaboration performance, and especially on those relational attributes instead of purely transactional factors, that have been identified at different levels of analysis. We have also provided some examples of its cross-level character and propose that our conceptualization can be used across levels and contexts. Collaboration capability is a multi-dimensional conceptualization consisting of three dimensions: trust, communication and commitment. Collaboration capability is defined as “actor's capability to build and manage network relationships based on mutual trust, communication and commitment”.

\section{COLLABORATION CAPABILITY IN KNOWLEDGE CREATION AND COLLABORATIVE INNOVATION}

Collaboration capability is especially important in dynamic and uncertain environment providing more unusual situations demanding coordinated action. Hence, knowing how to collaborate helps the firm to create and transfer knowledge for innovation and better performance. Miles et al. (2000) has illustrated the role of collaboration in the innovation process (Figure 2).

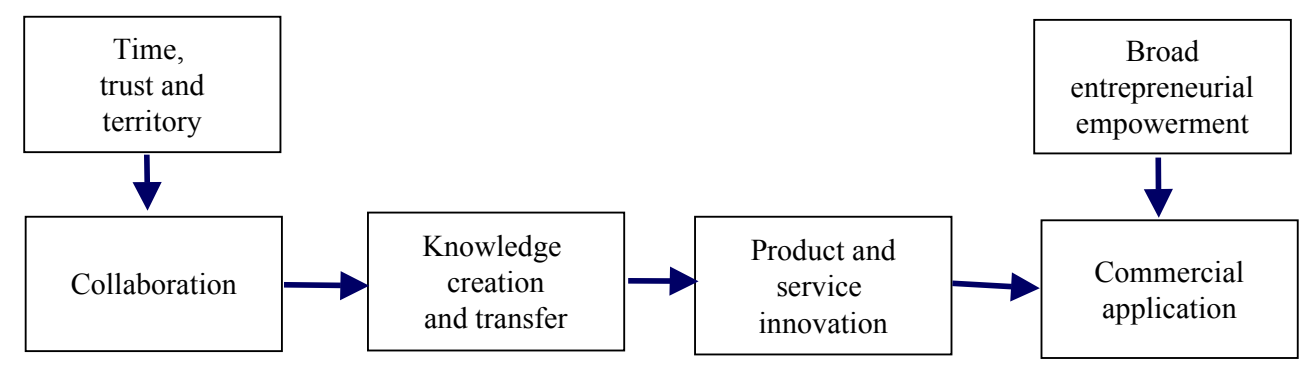

Figure 2. Role of Collaboration in Innovation Process (Miles et al. 2000) 
The model depicts in a simple and logical way the critical and interlinked role of collaboration in knowledge creation. Time, trust and shared mental territory are seen as pre-requisites for collaboration. Collaboration is a necessary antecedent for knowledge creation and transfer. Knowledge creation is always social in nature, and innovations emerge as a synthesis of complementary knowledge of asymmetric actors. Knowledge creation and utilization, in turn, can lead to innovation. Miles et al. (2000) point out also the need for a broad entrepreneurial empowerment for the innovation process and commercial applications. They bring explicitly forth collaboration as a meta-capability and emphasize the voluntary aspect of innovation: "innovation cannot be managed hierarchically because it depends on knowledge being offered voluntarily rather than on command" (Miles et al. 2000, 300). This is equally important in firm-internal and inter-firm collaboration. Without voice and empowerment the actors with diverse knowledge and ideas are not heard, and only a portion of the potential knowledge will be used. Collaboration as a meta-capability emphasizes the collaboration capability and the quality of the collaborative relationships with internal and external stakeholders (Miles et al. 2000).

In search for continuous innovation the role of collaboration capability, that is, the ability to build and manage relationships with other parties on individual, team, departmental, and organizational levels is highlighted. Innovative firms such as Corning, 3M and Toyota are known for their ability to harness cooperative competencies, i.e. human and and organizational collaboration competencies in both intra- and inter-organizational networks (Tyler 2001, Miles et al. 2000). Also Irwin et al. (1998) found the need to develop better relational competence as a critical issue in the innovation strategy.

Collaboration capability itself enables replacement of old capabilities, and internal or external development or acquisition of new capabilities. Collaboration capability can also be seen as part of the firm's transformational capacity (Garud and Nayar, 1994), that is the firm's capacity to continually redefine its product portfolio, based on technological opportunities created within the firm (Tyler 2001, 8).

\section{COLLABORATION CAPABILITY AND PERFORMANCE}

Development and commercialization of almost all innovations demand some form of collaboration. According to Heimeriks (2002) alliance performance is impacted by alliance capability and relationship quality, which consists of both economic and social factors. Resource configuration, partner compatibility and co-ordination can be seen as economic factors; and trust, commitment and communication as relational factors. Authors don't define collaboration capability but it would be 
logical to think that alliance capability would consist of capabilities to manage the dimensions of relationship quality.

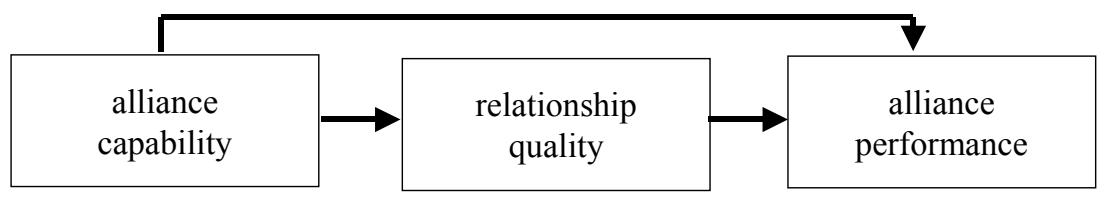

\section{Figure 3. Alliance Capability And Relationship Quality As Sources For Alliance Performance (Heimeriks 2002)}

We propose that the model by Heimeriks (2002) can be generalised to different levels of network interaction. Therefore also terms like collaboration capability, collaboration quality and collaboration performance could be used alternatively with the ones in the model. It is proposed that relational factors discern relation-oriented relationships from transactional relationships (Sarkar et al. 2001; Pillai \& Sharma 2003; Heide \& John 1992; Morgan \& Hunt 1994).

Unsuccessful alliances and coalitions often fail for a very simple reason - they are not created or utilized collaboratively (Miles et al., 2000). Subsequently continuous value creation and innovation in the dynamic environment is possible only in relationships with higher order relational qualities, such as trust, communication and commitment. These factors are also seen as key characteristics for successful inter-organisational collaboration (Blomqvist 2002, Medlin et al. 2002, Mohr and Spekman 1994) and leading to performance (Heimeriks 2002).

They may be critical also in intra-firm collaboration, where informal collaboration, e.g. communication and co-ordination have been shown to increase organisational performance through better interdepartmental co-ordination (see also Lawrence and Lorsch 1986, Tjosvold 1988, Souder 1987 and Ellinger et al 2000). According to Kahn and Mentzer's (1996 and 1998) research on interdepartmental integration collaborative approach had a significant positive relationship with performance. Instead, interdepartmental interaction without collaborative approach had no impact or even negative impact on performance. Also Ellinger et al. (2000, 2) distinguish collaborative interaction from transactional or hierarchical interaction. In their study collaboration was characterized as working informally together, sharing ideas, information and resources, and working together as a team. In their study on interdepartmental integration they found out that interpersonal communication strategies predicted almost $10 \%$ of firm performance. However, increasing the 
formal information exchange e.g. exchange of reports, memorandums or consultations in the form of committees did not improve performance.

Role of collaboration is accentuated in situations of high market or technological uncertainty, technological or organizational complexity, and resulting high need for information and knowledge creation (see also Tyler 2001). The effect of collaboration on performance is proposed to be higher when products and services are complex (Kahn 1996 and 1998), or in uncertain and dynamic economic periods (Miller and Shamsie 1996). It is proposed that under these conditions collaboration capability is an essential capability in a network economy, where competitiveness is based on knowledge and continuous innovation.

Collaboration capability can be seen as a source for competitive advance, as it is a valuable, difficult to imitate, rare and socially complex capability (Barney 1991). Ritter et al. $(2002,119)$ argue that network competence, "the ability of a firm to develop and manage relations with key suppliers, customers and other organizations and to deal effectively with the interactions among these relations" is a core competence of a firm - one that has a direct bearing on a firm's competitive strength and performance". Tyler (2001) suggests that collaboration capabilities can even compensate for average or potentially below average technological know-how when firms seek to innovate technologically. If we see collaboration capability as complement to technological capabilities (Tyler 2001), and a meta-capability enabling continuous development of dynamic capabilities (Miles et al. 2001, Blomqvist 2002 and Blomqvist and Seppänen 2003), it has a critical role in firm competitiveness, and may even become a source for sustainable competitive advantage.

\section{DISCUSSION AND CONCLUSION}

In this paper we have proposed collaboration capability as a focal concept for knowledge creation and collaborative innovation. Collaboration capability integrates the relational elements in many closely related, but semantically diversified conceptualizations: e.g. alliance capability, collective competence, co-operation competence, collaboration as a meta-capability, cooperative capabilities, and collaborative know-how. It emphasizes the relational perspective and enables knowledge creation in risky and uncertain environment. As a result of our analysis we propose that collaboration capability may be an integrating concept enabling and explaining much of the success in knowledge creation and collaborative innovation. 
Both Miles et al (2000) and Heimerik's (2002) models are useful, as they can be used independent of the level of analysis, e.g. at a level of a team, department, firm or a network of firms. It is proposed that collaboration and innovation are cross-level concepts emerging in social interaction, and such that they cannot be discerned at a certain level only (see e.g. Rosseau et al. 1998, Weiss 1993 and Kanter 1988).

As discussed by Miles et al. (2004) collaboration should be given a distinct meaning. In the knowledge-based global competition cooperation as a co-ordinated action based only on extrinsic motivation and economic rationale is not sufficient. However, as argumented in this paper, the economic approach is not sufficient to ensure performance in the dynamic environment. In order to manage with complex tasks and high uncertainty, a higher-order interaction between different parties is needed. As described by Blomqvist in introducing the concept of fast trust (2002) role-based narrow interaction is not enough to bridge asymmetric actors under uncertainty. Both fast trust and collaboration capability are based on care and affect. In addition to extrinsic motivation they both involve intrinsic motivation of knowledge workers, the joy of working, learning and satisfaction of accomplishing together. These higher-order concepts describing deeper interaction in networks are useful to identify and understand the critical factors for continuous innovation and sustainable competitive advantage in the dynamic and uncertain network economy.

Collaboration capability has thus a distinct meaning and emphasizes the relational aspects. It is clearly a multi-dimensional concept. Based on earlier literature we propose that the dimensions of collaboration capability: trust, communication and commitment, are the key factors distinguishing relational exchange from transactional exchange, and essential for knowledge creation and collaborative innovation in networks. Collaboration capability is defined as "actor's capability to build and manage network relationships based on mutual trust, communication and commitment".

The emerging body of literature on e.g. alliance capabilities, their nature and possibilities to develop firm-specific alliance capabilities has taken a very concrete and managerial approach by defining different organisational structures, mechanisms and micro-processes as a source for alliance capability. Especially Duysters, Heimeriks and Jurriëns (2003) refer to corporate level mechanisms enhancing organisational learning and capabilities, such as alliance department, alliance database and partner selection program. Micro-mechanisms as described by e.g. Duysters et al. 2003 are seen as tools to implement collaboration capability in practice. They can, and should, be implemented in different levels of analysis: in addition to alliances also at individual, team, intra-organisational and finally at a network level. This stream of research is concrete enough to have a strong promise for 
managerial implications and guidance. However, at present the relational aspects emphasised in our conceptualisation for collaborative capability are left for lesser attention. In future research on alliance capabilities it would be useful to emphasise also the collaboration capability. Also, in the future incorporating concepts from organizational learning perspective and knowledge management could be fruitful. The present research on alliance capabilities does not take into account of the critical issue e.g. how to transfer tacit knowledge between different collaborative relationships.

We also propose that collaboration capability can be used as a cross-level concept. It is a useful concept to understand network activities at all levels of analysis. There has been however very little research where different levels of analysis are combined. A more holistic approach is needed to understand the systemic nature of networks, as collaboration capability at different levels (individuals, team, department, organisation, a dyad) impact each other, and the performance of the network.

For researchers in business-to-business relationships it is important to validate the role and nature of focal concepts. For most managers it is the corporate metrics that guides their action in the end of the day. As a separate task we have been developing a pilot measurement instrument for collaboration capability. A global machine manufacturer attempting to develop their supplier relationships towards relational approach will pilot this instrument. Thereafter its suitability for a cross-level measurement instrument could be studied by incorporating also other levels of analysis.

Collaboration is always a "two-way-street" where one's own collaboration capability impacts very much both the relationship quality and the subsequent mutual performance. Universal metrics for team level, intra-firm collaboration and inter-firm collaboration could make it more understandable for each individual, as similar metrics and language would be used both internally and externally. A universal and cross-level metrics for collaboration capability would emphasise the relational perspective at all levels. From a managerial perspective emphasis on one focal concept and related metrics at different levels would help the often very challenging change management towards relational attitudes and behaviour. 


\section{REFERENCES:}

Ala-Pietilä Pekka (2003). A Key Note Speech in Conference for Knowledge Management at Helsinki School of Business and Economics, August 21-22.

Amit, Raphael and Schoemaker, Paul J H. (1993). Strategic Assets And Organizational Rent in Strategic Management Journal, Vol. 14, Iss. 1, 33-46

Anand, Bharat N. and Khanna, Tarun (2000). Do Firms Learn to Create Value? The Case of Alliances in Strategic Management Journal, 21, 295-315.

Barney J. (1991). Firm Resources and Sustained Competitive Advantage in Journal of Management 17(1): 99-120.

Bello, Daniel C., Chelariu, Cristian and Zhang, Li (2003). The Antecedents And Performance Consequences Of Relationalism In Export Distribution Channels in Journal of Business Research, Volume 56, No 1, 1-16.

Blomqvist, Kirsimarja and Seppänen, Risto (2003). Bringing Together the Emerging Theories on Trust and Dynamic Capabilities - Collaboration and Trust as Focal Concepts. A paper presented in the $19^{\text {th }}$ Annual IMP Conference, $4^{\text {th }}-6^{\text {th }}$ of September 2003, Lugano, Switzerland.

Blomqvist, Kirsimarja (2002). Partnering in the Dynamic Environment: The Role of Trust in Asymmetric Technology Partnership Formation, doctoral thesis, Acta Universitatis Lappeenrantaensis.

Buckley, Peter J., Glaister, Keith W. and Husan, Rumy (2002). International Joint Ventures: Partnering Skills and Cross-Cultural Issues in Long Range Planning 35, 113-134.

Contractor, F. J. and Lorange, P. (2002). The Growth Of Alliances In The Knowledge-Based Economy. International Business Review 11, 485-502.

Crosby, Lawrence A., Evans, Kenneth R. and Cowles, Deborah (1990). Relationship Quality in Services Selling: An Interpersonal Influence Perspective in Journal of Marketing, Vol. 54, No 3, 68-81.

Draulans Johan, deMan Ard-Pieter and Volberda Henk W. (2003). Building Alliance Capability: Management Techniques for Superior Alliance Performance in Long Range Planning 36, 151-166.

Duysters, Geert, Heimeriks, Koen H. and Jurriëns, Jan (2003). Three Levels of Alliance Management. Working paper, Eindhoven Centre for Innovation Studies (ECIS), Eindhoven University of Technology

Dyer, Jeffrey H. and Singh, Harbir (1998). The Relational View: Cooperative Strategy and Sources of Interorganizational Competitive Advantage in Academy of Management Review, Vol. 23, No 4, 660-679.

Eisenhardt K.M. and Martin J.A. (2000). Dynamic Capabilities: What are they? in Strategic Management Journal Special Issue 21, No 10-11, 1105-1121.

Ellinger Alexander E., Daugherty Patricia J. and Keller Scott B. (2000). Their Relationship between Marketing/Logistics Interdepartmental Integration and Performance in US Manufacturing Firms: An Empirical Study in Journal of Business Logistics, Vol. 21, No. 1, 1-22.

Ford, David (2002). The Business Marketing Course: Managing in Complex Networks. Chichester: Wiley.

Ganesan, Shankar (1994). Determinants Of Long-Term Orientation In Buyer-Seller Relationships in Journal of Marketing. Chicago: Apr 1994. Vol. 58, No. 2, 1-19.

Grant R. (1996). Toward A Knowledge-Based View of The Firm in Strategic Management Journal, Winter Special, No 17, 109-122. 
Grant, Robert M. (1991). The Resource-Based Theory of Competitive Advantage: Implications for Strategy Formulation in California Management Review. Vol. 33, No 3, 114-135.

Gulati, Ranjay; Nohria, Nitin and Zaheer, Akbar (2000). Strategic Networks in Strategic Management Journal. Vol. 21, No. 3. 203-215

Hafeez, K., Zhang, Y. \& Malak N. (2002). Core Competence for Sustainable Competitive Advantage: A Structured Methodology for Identifying Core Competence in IEEE Transactions on Engineering Management. Vol. 49, No. 1, 28-36

Heide, Jan B. \& John, George (1992). Do Norms Matter in Marketing Relationships? Journal of Marketing, Vol.56, No. 2, 32-44.

Heimeriks, Koen H. \& Duysters, Geert M. (2003). Experience and Capabilities to Explain Alliance Performance: Substitutes or Complements? Eindhoven Centre for Innovation Studies (ECIS). Eindhoven University of Technology, The Netherlands.

Heimeriks, Koen (2002). Alliance Capability, Collaboration Quality, and Alliance Performance: An integrated Framework. Eindhoven Centre for Innovation Studies (ECIS), working paper. Eindhoven University of Technology, The Netherlands.

Hillebrand, Bas and Biemans, Wim G. (2003). The Relationship Between Internal And External Cooperation: Literature Review And Propositions in Journal of Business Research. 2003. Vol. 56, No 9, 735-744

Håkansson H, Snehota I. (1995). Developing Relationships In Business Networks. London: International Thomson Business Press.

Irwin, Harry; More Elizabeth and McGrath Mike (1998). Relationship Management for Innovation: The Central Role of Communications in Australia's Participation in Two Hi-tech Industries in Technology Analysis and Strategic Management, Vol. 10, No. 4, 467-481.

Javidan, Mansour (1998). Core Competence: What Does It Mean In Practice? in Long Range Planning, Vol. 31, No. 1; 60-72.

Järvenpää, Sirkka L. and Leidner, Dorothy E (1999). Communication And Trust In Global Virtual Teams. Organization Science. Linthicum: Nov/Dec 1999. Vol. 10, No 6, 791-815.

Kahn, Kenneth B. and Mentzer John T. (1996). Logistics and Interdepartmental Integration in International Journal of Physical Distribtuion \& Logistics Management, Vol. 26, No. 8, 6-14.

Kahn, Kenneth B. and Mentzer, John T. (1998). Marketing's Integration with other Departments in Journal of Business Research 42, 53-62.

Kale, Prashant; Dyer, Jeffrey H. and Singh, Harbir (2002). Alliance Capability, Stock Market Response, And Long-Term Alliance Success: The Role Of The Alliance Function in Strategic Management Journal, Vol. 23, Issue $8,747-767$.

Kanter. R.M. (1988). When a Thousand Flower Boom: Structural, Collective, and Social Conditions for Innovations in Organization. In: Cummings, L.L., Staw B.M (Eds). Research in Organizational Behavior. Vol. 10, JAI Press, Greenwich, CT, 169-211.

Kogut, Bruce and Zander, Udo (1993). Knowledge Of The Firm And The Evolutionary Theory Of The Multinational Corporation. Journal of International Business Studies. Washington: Fourth Quarter Vol. 24, No. 4, 625-645. 
Lambe, C. Jay; Spekman, Robert E. and Hunt, Shelby D. (2002). Alliance Competence, Resources, And Alliance Success: Conceptualization, Measurement, And Initial Test. Academy of Marketing Science, Vol. 30, No. 2, 141-158.

Maccoby, Michael (2000). Creating Network Competence in Research Technology Management, Vol. 43, 3, 59-60.

Makadok, Richard (2001). Toward A Synthesis Of The Resource-Based And Dynamic-Capability Views Of Rent Creation in Strategic Management Journal, Vol. 21, No 5, 387-401.

Miles, Raymond E., Snow, Charles C. and Miles, Grant (2004). Collaborative Entrepreneurship. How Groups of Networked Firms Use Continuous Innovation to Create Economic Wealth? Stanford, Ca: Stanford University Press, Forthcoming.

Miles, Raymond E., Snow, Charles C. and Miles, Grant (2000). TheFuture.org in Long Range Planning, 33, 300-321.

Miller, Danny and Shamsie, Jamal (1996). The Resource-Based View Of The Firm In Two Enviroments: The Hollywood Film Studios From 1936 To 1965 in Academy of Management Journal, Vol. 39, No, 3, 519-544.

Mohr, Jakki and Spekman, Robert (1994). Characteristics Of Partnership Success: Partnership Attributes, Communication Behavior, And Conflict Resolution Techniques. Strategic Management Journal, Vol. 15, No. 2, 135-152.

Morgan, Robert M. \& Hunt, Shelby D. (1994). The Commitment-Trust Theory Of Relationship Marketing in Journal of Marketing. Vol. 58, No 3, 20-38.

Niemelä, Tarja (2003). Inter-Firm Co-Operation Capability In The Context Of Networking Family Firms: The Role Of Trust. Working paper, University of Jyväskylä.

Nonaka, I. and Takeuchi, H. (1995). The Knowledge-Creating Company. How Japanese Companies Create The Dynamics Of Innovation. New York: Oxford University Press.

Pillai, Kishore Gopalakrishna \& Sharma, Arun (2003). Mature Relationships: Why Does Relational Orientation Turn Into Transaction Orientation? Industrial Marketing Management 32, 643-651.

Prahalad C.K. and Hamel G. (1990). The Core Competence of The Corporation. Harvard Business Review (May), 79-91.

Ritter, Thomas \& Gemunden, Hans Georg (2003). Network Competence: Its Impact On Innovation Success And Its Antecedents in Journal of Business Research 56, 745- 755.

Ritter T., Wilkinson I.F. and Johston W.J (2002). Measuring Network Competence: Some International Evidence in The Journal of Business \& Industrial Marketing, 17, 2/3, 119-138.

Rousseau, D.M. (1985). Issues of Level in Organizational Research: Multi-Level Perspectives. In: Cummings, L.L., Staw, B.M (Eds.), Research in Organizational Behavior, Vol. 7. JAI Press, Greenwich, CT, 1-38.

Rousseau, Denise M.; Sitkin, Sim B.; Burt, Ronald S. and Camerer, Colin (1998). Not So Different After All: A Cross-Discipline View of Trust in Academy of Management Review, Vol. 23, No 3, 393-404. 
Sarkar, M.B., Echambadi, Raj S., Cavusgil, Tamer and Aulakh, Preet S (2001). The Influence Of Complementarity, Compatibility, And Relationship Capital On Alliance Performance In Academy of Marketing Science. Vol. 29, No 4, 358-373.

Simonin, Bernard L. (1997). The Importance Of Collaborative Know-How: An Empirical Test Of The Learning Organization in Academy of Management Journal. Vol. 40, No 1, 1150-1174.

Smith, K.G., Carrol S.J., Asford, S.J. (1995). Intra- and Inter-organizational Cooperation: Toward a Research Agenda in Academy of Management Journal, Vol. 38, No. 1, 7-23.

Sivadas, Eugene and Dwyer, F. Robert (2000). An Examination Of Organizational Factors Influencing New Product Success In Internal And Alliance-Based Processes in Journal of Marketing; Jan 2000, Vol. 64, No 1, $31-49$.

Storbacka, Kaj; Strandvik, Tore and Grönroos, Christian (1994). Managing Customer Relationships For Profit: The Dynamics Of Relationship Quality in International Journal of Service Industry Management, Vol. 5, No 5, 21-38.

Swink, Morgan (1999). Threats to New Product Manufacturability and the Effects of Development Team Integration Process in Journal of Operations Management 17, 691-709

Teece D.J, Pisano G and Shuen A. 1997. Dynamic Capabilities and Strategic Management in Strategic management Journal, Vol. 18, No. 2, 509-533.

Tyler, Beverly B. (2001). The Complementarity of Cooperative and Technological Competencies. A Resource-based Perspective in Journal of English Technology Management, 18, 1-27.

Vartiainen, M., Kokko, N. and Hakonen, M. (2003). Competences in Virtual Organizations. A paper presented in 2rd International conference of researching work and learning. Tampere, Finland.

Weiss, S.E. (1993). Analysis of Complex Negotiations in Intenational Business: the RBC Perspective in Organization Science Vol 4, No. 2, 269-300.

Wernerfelt B. 1984. A Resource-Based View Of The Firm in Strategic Management Journal, Vol. 5, No 2, 171-180.

Wieselquist, Jennifer; Rusbult, Caryl E.; Foster, Craig A. and Agnew, Christopher R. (1999). Commitment, Pro-Relationship Behavior, and Trust in Close Relationships in Journal of Personality and Social Psychology. Washington: Vol. 77, Iss. 5. 